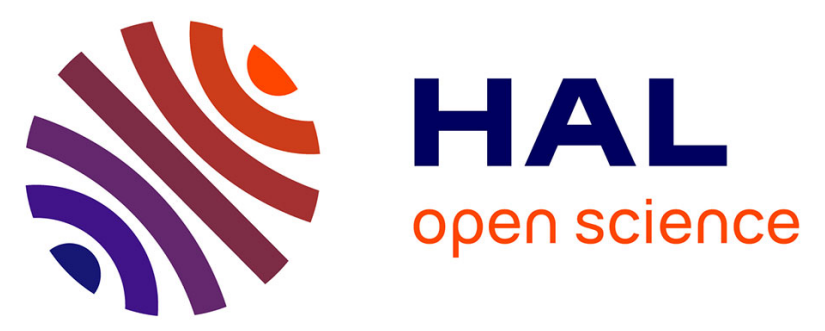

\title{
FOLFIRINEC: a randomized phase II trial of mFOLFIRINOX vs platinum-etoposide for metastatic neuroendocrine carcinoma of gastroenteropancreatic or unknown origin
}

Julien Hadoux, Pauline Afchain, Thomas Walter, David Tougeron, Vincent Hautefeuille, Carole Monterymard, Véronique Lorgis, Frédéric Thuillier, Eric Baudin, Jean Yves Scoazec, et al.

\section{- To cite this version:}

Julien Hadoux, Pauline Afchain, Thomas Walter, David Tougeron, Vincent Hautefeuille, et al.. FOLFIRINEC: a randomized phase II trial of mFOLFIRINOX vs platinum-etoposide for metastatic neuroendocrine carcinoma of gastroenteropancreatic or unknown origin. Digestive and Liver Disease, 2021, 53 (7), pp.824-829. 10.1016/j.dld.2021.04.016 . hal-03333521

\section{HAL Id: hal-03333521 \\ https://hal.sorbonne-universite.fr/hal-03333521}

Submitted on 3 Sep 2021

HAL is a multi-disciplinary open access archive for the deposit and dissemination of scientific research documents, whether they are published or not. The documents may come from teaching and research institutions in France or abroad, or from public or private research centers.
L'archive ouverte pluridisciplinaire HAL, est destinée au dépôt et à la diffusion de documents scientifiques de niveau recherche, publiés ou non, émanant des établissements d'enseignement et de recherche français ou étrangers, des laboratoires publics ou privés. 
27 * Corresponding author:

Authors:

Affiliations: University, Lyon, France Poitiers, France Dijon, France Franche Comté, Dijon, France Malo

Dr Julien Hadoux

FOLFIRINEC: randomized phase II trial of mFOLFIRINOX vs platinum-etoposide for metastatic neuroendocrine carcinoma of gastroenteropancreatic or unknown origin.

Julien Hadoux ${ }^{a \star}$, Pauline Afchain ${ }^{b}$, Thomas Walter $^{c}$, David Tougeron ${ }^{d}$, Vincent Hautefeuille ${ }^{e}$, Carole Monterymard ${ }^{\ddagger}$, Véronique Lorgis ${ }^{\mathfrak{g}}$, Frédéric Thuillier ${ }^{\mathrm{h}}$, Eric Baudin ${ }^{\mathrm{a}}$, Jean Yves Scoazeci, Côme Lepage, ${ }^{\mathrm{f}, \mathrm{j}}$ and Romain Desgrippes ${ }^{\mathrm{k}}$

a - Endocrine oncology, Imaging department, Gustave Roussy, Villejuif, F-94805 Villejuif

b - Department of Oncology, Saint Antoine Hospital, Paris, France

c - Department of Oncology, ENETS Centre of Excellence, Hospices Civils de Lyon and Lyon

d - Department of Hepato-gastroenterology, Poitiers University Hospital; University of Poitiers,

e - Department of Hepato-gastroenterology, Amiens University Hospital, Amiens, France

f - FFCD EPICAD INSERM LNC-UMR 1231, University of Burgundy and Franche-Comté,

g - Department of Oncology, Cancerology institut of Bourgogne GRReCC, Dijon, France

h - Department of Oncology, Limoges University Hospital, Limoges, France

i - Pathology, Biopathology department, Gustave Roussy, Villejuif, F-94805 Villejuif

j - Department of digestive oncology University hospital Dijon; University of Burgundy and

k - Hepato-gastroenterology department, Centre Hospitalier de Saint-Malo, F-35403 Saint- 
29 Gustave Roussy, 114 rue Edouard Vaillant, 94805 Villejuif

$30 \quad$ Julien.hadoux@gustaveroussy.fr

$31+33142116361$

32

33 Keywords

34 Neuroendocrine carcinoma

35 Gastroenteropancreatic

36 Chemotherapy

37 FOLFIRINOX 


\section{ABSTRACT}

\section{Background}

Poorly differentiated neuroendocrine carcinomas (NEC) are rare diseases with a poor prognosis. Platinum-etoposide (PE) has been the recommended first-line treatment for decades. FOLFIRINEC (NCT04325425) is a national multicenter randomized phase II study which aims to challenge this standard regimen.

\section{Methods}

The primary objective is to compare the median progression-free survival (PFS) under mFOLFIRINOX versus PE. The secondary objectives are to evaluate the objective response rates (ORR), median overall survival (OS), safety and quality of life. The associated real-time translational study will establish a molecular profile for each patient enrolled.

Main inclusion criteria are: NEC of gastroenteropancreatic (GEP) or unknown origin, metastatic and RECIST 1.1 evaluable disease, tumor sample available and no contraindication to chemotherapy. Patients will be randomized $1: 1$ between PE every 21 days for $6-8$ cycles and mFOLFIRINOX every 14 days for up to 12 cycles and stratified according to center, performance status, Ki67 and pathological subtype.

This trial will randomize 218 patients (24 months of follow-up) to have $80 \%$ power to detect an improvement of the median PFS from 5 months under PE to 7.5 months under mFOLFIRINOX (HR of $0.67, \alpha=5 \%$, two-sided). An intermediate analysis is planned at $50 \%$ of events.

Recruitment started on October 20, 2020. 


\section{Rational and aims}

Poorly differentiated neuroendocrine carcinomas (NEC) of gastroenteropancreatic (GEP) and unknown origins are rare and heterogeneous diseases. The diagnosis is often done at the metastatic stage and the prognosis is poor. The standard first-line (L1) treatment is platinum-etoposide (PE) combination chemotherapy, mostly based on retrospective studies $[1,2]$. With this regimen, $R R$ is 40 to $70 \%$ but the median PFS is short, between 4 and 9 months $[3,4]$. Disease progression almost always occurs during or just after treatment and median overall survival (OS) is only about 12-15 months for GEP NEC with similar efficacy of either cisplatin or carboplatin $[3,4]$ and of either oral or intravenous etoposide $[5,6]$. After progression, only 40 to $45 \%$ of patients will receive a second-line (L2) chemotherapy which will include 5fluoro-uracil (5FU) or capecitabine and irinotecan (FOLFIRI [7]) or oxaliplatin (XELOX, FOLFOX [8]) or dacarbazine/temozolomide [9]. This second-line treatment can provide about $30 \%$ of RR and a median PFS of 4 months $[4,7,8]$. Taken together, these data indicate a major medical need for improving NEC treatments.

Since the first description, thirty years ago, of the PE combination efficacy for what was called "anaplastic neuroendocrine carcinomas" and referred nowadays to NEC by Moertel and collaborators, no change has been made to this standard of care [10]. Only one randomized phase II trial have compared the efficacy of the cisplatin - irinotecan (PI) combination to the standard PE regimen. This phase II enrolled 66 patients and was terminated prematurely following interim analysis showing equivalent efficacy. Indeed, the objective RR were similar in both arm (42.4\%), the median PFS was 6.4 months in the PE arm and 5.8 months in the PI arm, respectively $(p=0.81)$, and the median OS was 11.3 months and 10.2 months, respectively, $(p=0.37)$ [11]. A single arm phase II study evaluated PE intensification with the addition of paclitaxel and found an objective RR of $53 \%$, a median PFS of 7.5 months and a median OS of 14.5 months which led the authors to conclude to the absence of higher efficacy as compared to the standard PE regimen [12]. Other studies are almost all retrospective and have reported equivalent efficacies of either $\mathrm{PE}$ or $\mathrm{PI}$, except the Yamaguchi et al. study 
suggesting higher efficacy of PI regimen but this study was not randomized, the studies of firstline chemotherapy in NEC are summarized in Table 1.

Although all studies on second-line treatment of metastatic NEC of GEP or unknown origin were retrospective, they have suggested that both irinotecan and oxaliplatin, in combination with 5FU can have anti-tumor effect in NEC $[7,8]$. In the last decade, the FOLFIRINOX triplet chemotherapy regimen, combining 5FU, oxaliplatin and irinotecan, has shown significant efficacy in several digestive cancers such as pancreas [13] or colorectal adenocarcinoma [14]. Tolerance of this regimen has improved over the years with better tolerability that has led to the development of the mFOLFIRINOX regimen [15]. mFOLFIRINOX could be a good L1 treatment in metastatic GEP NEC because: (i) Oxaliplatin, irinotecan and 5FU have anti-tumor effect in metastatic GEP NEC [4,7,8]; (ii) triplet with a potential high RR could be efficient in these chemosensitive cancers; (iii) the degradation of PS following tumor progression during/after L1 treatment makes access to a second-line uncertain which argue for the use of an aggressive L1 treatment; (iiii) administration on a one-day outpatient basis (day hospital), as well as acceptable adverse events, could have an impact on quality of life in these patients with a poor prognosis. With the PRODIGE 69-FOLFIRINEC trial hypothesize that the mFOLFIRINOX triplet may improve the prognosis of patients with metastatic NEC from GEP or unknown primary.

Few data are available on predictive factors of $L 1$ chemotherapy efficacy in metastatic NEC which are subdivided in 2 main pathological subtypes; eg. small cell NEC (SCNEC) and large cell NEC (LCNEC). These two subtypes are treated with the same PE regimen, whatever the primary tumour site, although overall response rate (ORR) seem to differ between SCNEC (about 50 to $70 \%$ ) and LCNEC (about 30-50\%) in lung and pancreas NEC retrospective series [16-19]. These data have led to the choice of stratifying the FOLFIRNIEC trial according to pathological subtypes. Few studies have reported molecular profiles of NEC with a perspective of personalized treatment. Previous studies have mainly focused on BRAF mutation in colon NEC and the efficacy of the dabrafenib-trametinib combination [20-22], contrary to what is observed in colon adenocarcinoma, which has been suggested to be related to an epigenetic 
114 silencing of the epidermal growth factor receptor in colon NEC [21]. Moreover, little is known 115 on the putative predictive biomarkers to immunotherapy efficacy in NEC of GEP and unknown 116 origin. Tumour mutational burden (TMB) is between 8.6 and 10.5 mutations/megabase in NEC 117 of the lung $[23,24]$ but no data exist for GEP and unknown origin NEC. In addition MLH1 and 118 PMS2 loss of expression by immunohistochemistry mostly due to MLH1 promoter methylation 119 (dMMR phenotype) have been reported in 12.4\% tumoral samples of a series of 89 GEP NEC 120 and mixed neuroendocrine neoplasms [25]. In an attempt to expand knowledge on molecular 121 alterations in NEC of GEP and unknown origin, the FOLFIRINEC-PRODIGE 69 phase II trial 122 is associated with a "real time" translational study which will establish the tumor molecular 123 profile of each participating patients for whom tumoral sample is available. 


\section{Study design}

The PRODIGE 69-FOLFIRINEC study is a national, multicentre, prospective, openlabel, randomized and trial comparing the efficacy of mFOLFIRINOX versus PE regimen for the treatment of patients with metastatic NEC of GEP and unknown origin associated with a molecular profiling for therapeutic targets and biomarkers identification (Figure 1).

Eligible patients will be stratified according to ECOG PS ( 0 vs 1), Ki67 ( $<55 \%$ vs $\geq 55 \%$ ) and pathological subtype (small cell vs large cell or unknown) and then randomly assigned $(1: 1)$ to either standard regimen arm with platinum (cisplatin $100 \mathrm{mg} / \mathrm{m}^{2}$ day 1 or carboplatin AUC 5 day 1, according to physician's choice) and etoposide (100 mg/m² intravenous (IV), day 1, 2 and 3) administered every 21 days for 6 to 8 cycles (24 weeks maximum) or experimental treatment arm with mFOLFIRINOX (oxaliplatin $85 \mathrm{mg} / \mathrm{m}^{2} \mathrm{IV}$ + irinotecan $180 \mathrm{mg} / \mathrm{m}^{2} \mathrm{IV}$ + LV5FU2 $2400 \mathrm{mg} / \mathrm{m}^{2}$ without 5 FU bolus) administered every 14 days for 12 cycles (24 weeks maximum). years, ECOG PS 0 or 1, with a metastatic NEC or high grade MiNEN with a NEC component $\geq 30 \%$, of GEP or unknown origin, whatever the pathological subtype (small cell or large cell or non-small cell or unknown/indetermined) (Table 2). Grade 3 well-differentiated neuroendocrine tumors according to WHO 2017 classification are not eligible. Patient must not have received any prior therapy for metastatic disease. Patient with asymptomatic brain metastases or under stable corticosteroid doses for at least 2 weeks before randomization can be included; otherwise, radiation therapy prior to inclusion is required in case of symptomatic brain metastases. Patient must have adequate haematology parameters (neutrophil count $\geq$ $1.5 \times 10^{9} / \mathrm{L}$, platelet $\geq 100 \times 10^{9} / \mathrm{L}$ and hemoglobin $>8 \mathrm{~g} / \mathrm{dL}$ ), a creatinine clearance above 30 $\mathrm{ml} / \mathrm{min}$ (Cockroft \& Gault formula) and adequate liver function (total bilirubin $\leq 1.5 \mathrm{~N}, \mathrm{AST} / \mathrm{ALT}$ $\leq 2.5 \mathrm{~N}$, or $\mathrm{AST} / \mathrm{ALT} \leq 5 \mathrm{~N}$ in case of liver metastases). All patients must undergo dihydropyrimidine dehydrogenase (DPD) deficiency screening and cannot be included in case of uracilemia $\geq 16 \mathrm{ng} / \mathrm{mL}$. Other standard exclusion criteria are applied: pregnancy, history of 
recent malignancy, active HIV or viral hepatitis and any active or suspected acute or chronic uncontrolled disease that would impair study participation.

The radiological assessment will be performed at baseline (within a maximum of 3 weeks before inclusion) using a TAP computed tomography (CT) scan (or magnetic resonance imaging (MRI) of the abdomen plus chest CT-scan in case of contrast medium allergy), and the same procedure (CT and/or MRI) will be repeated every 8 weeks until tumor progression or death. Radiological tumor assessment will be performed according to the RECIST v1.1 criteria. Brain imaging is required at baseline either by CT-scan and/or MRI. Imaging of brain lesions by CT-scan and/or MRI is required every 8 weeks (+/- 1 week) during treatment and follow-up if present at baseline.

\subsection{Study endpoints}

The primary endpoint is the median PFS. PFS is defined as the time interval between date of randomization and date of the first radiological progression (according to RECIST 1.1) or death due to any cause, whichever occurs first, according to the investigator. Patient alive without progression will be censored at date of last follow-up visit.

The secondary endpoints are:

- centralized PFS by independent reviewed

- OS which is defined as the time between date of randomization and date of death (whatever the cause). Patients alive will be censored at date of last news.

- Best objective RR which is defined as the proportion of patients with an objective response (complete response $(\mathrm{CR})+$ partial response $(\mathrm{PR}))$ at any evaluation during the treatment, according to RECIST 1.1 and centralized review.

- Safety which is defined as the percentage of patients who experienced toxicities and grading of these toxicities according to $\mathrm{NCl}-\mathrm{CTC}$ V4. Toxicities will be presented as the number of patients presenting at least one toxicity by maximum grade.

- Dose reductions and dose intensity which are defined as the number of treatment cycles, the dose received and the percentages of actual dose received as compared to the 
theoretical dose will be described, as well as the percentage of patients with at least one dose modification/reduction or at least one postponement of chemotherapy.

- Quality of life assessed by the EORTC QLQ-C30 and EQ-5D-5L questionnaires.

- Exploratory analyses (see "biomarkers analyses"). The predictive value of each molecular alterations will be evaluated using correlation with objective RR, PFS and OS, in both arms.

\subsection{Ethical considerations}

This study is sponsored by the Fédération Francophone de Cancérologie Digestive (FFCD) and Dijon University hospital. PRODIGE 69-FOLFIRINEC has been authorized by the French medicines agency (Agence Nationale de Sécurité du Médicament et des produits de santé, ANSM) on March 23, 2020. It was submitted and approved (July 20, 2020) by the ethics committee (Comité de protection des personnes, CPP). This trial is registered on the European Union Clinical Trials Register (EudraCT no. 2019-001013-16) and on the clinicaltrials.gov website (NCT04325425). The study complies with the Declaration of Helsinki and the principles of Good Clinical Practice guidelines.

\subsection{Statistical methods}

For the primary endpoint, the median PFS will be calculated among patients who have received at least one dose of chemotherapy, whatever the dose and the treatment (modified intent-to-treat). Median PFS will be given for each treatment arm with their two-sided 95\% confidence interval. The Kaplan-Meier method (Kaplan and Meier, 1958) will be used to estimate median and curves will be plotted. Log-rank test will be used to compare the 2 treatment arms. Hazard ratios will be calculated using Cox proportional model (Cox, 1984). Proportionality (Schoenfeld residual methods) and linearity (Martingale residuals) hypotheses will be checked.

The hypothesis of the PRODIGE 69-FOLFIRINEC trial is that mFOLFIRINOX could increase median PFS from 5 months in the control arm (PE) to 7.5 months in the experimental $\operatorname{arm}(\mathrm{H} 1)$. 
With a two-sided risk alpha of $5 \%$ and a power of $80 \%, 203$ events (radiographic progression or death) are required to demonstrate a median PFS difference of 2.5 months $(\mathrm{HR}=0.67)$. With 24 months of follow-up, an inclusion rate of 5 patients/month and a lost-tofollow-up rate of $5 \%, 218$ patients will be randomized.

An intermediate analysis is planned at $50 \%$ of events (102 radiographic progression or death). The intermediate analysis is planned in order to show efficacy at an early stage (rejection of $\mathrm{HO}$ ) or futility (accept $\mathrm{H} 0$ ). The $\mathrm{p}$-values will be calculated using the O'BrienFleming function based on the real number of events.

As G3 NEC is a rare disease, 48 centers will be open to recruitment throughout France.

\subsection{Biomarker analysis}

This study includes a real-time, centralized molecular profiling of the tumor consisting of immunohistochemistry (IHC) markers (PD-L1 (Programmed death-ligand 1), Rb (retinoblastoma protein), TP53, MLH1 (MutL Homolog 1)) and a targeted next generation sequencing (NGS) panel of 161 genes (Oncomine Comprehensive assay V3, ThermoFisher ${ }^{\odot}$, Waltham, Massachusetts, US) associated with the determination of mutational tumor burden (TMB) and microsatellite instability status (MSI). This molecular profile will be reviewed by a molecular tumor board and the report will be sent to the investigator, together with the molecular profile results, within 2 months of tumor sample submission for informing further line treatment-decision making in the case of targetable alterations.

\section{Conclusion}

PRODIGE 69 - FOLFIRINEC is designed to challenge the standard platinum-etoposide combination chemotherapy with mFOLFIRINOX for the treatment of patients with NEC of GEP and unknown origin. The associated translational study aims at identifying biomarkers of responses in these patients and to draw the mutational landscape of these tumors with the goal to find targets for personalized medicine. The first patient was included on October 20, 2020, the end of inclusion is scheduled for the end of 2024. 


\section{Aknowledgment}

237 Lila Gaba, Marie Moreau, Sascha Moccozet, Laethicia Ndong, Caroline Choine, Jaïque Cario,

238 Charlène Barreaux, and all the clinical research associate and staff from CHU de Dijon \&

239 Fédération Francophone de Cancérologie Digestive (FFCD)

240 Ludovic Lacroix, Corinne Brandy, Leslie Girard, Zsofia Balogh, Malika Abdi and all the Gustave

241 Roussy personalized medicine and biopathology staff for the translational study:

242 We thank all the research and clinical networks involved: GERCOR, UNICANCER, FFCD, 243 ENDOCAN-RENATEN.

244 We thank all the participating centers research and clinical teams and the patients.

245

246 Conflict of interests:

247 None

$249 \quad$ Funding

250 The study is funded by the French National Cancer Institute (PHRC-K18 139).

251

252

\section{Source of support}

253 Supported by Clinical Research Hospital Program grants (PHRC-K 2018) from the French 254 ministry of health (PHRC-K18 139). 
257 [1] Pavel M, Öberg K, Falconi M, Krenning EP, Sundin A, Perren A, et al. 258 Gastroenteropancreatic neuroendocrine neoplasms: ESMO Clinical Practice Guidelines for 259 diagnosis, treatment and follow-up. Ann Oncol 2020;31:844-60. 260 https://doi.org/10.1016/j.annonc.2020.03.304.

261 [2] de Mestier L, Lepage C, Baudin E, Coriat R, Courbon F, Couvelard A, et al. Digestive 262 Neuroendocrine Neoplasms (NEN): French Intergroup clinical practice guidelines for 263 diagnosis, treatment and follow-up (SNFGE, GTE, RENATEN, TENPATH, FFCD, GERCOR, 264 UNICANCER, SFCD, SFED, SFRO, SFR). Dig Liver Dis 2020;52:473-92. https://doi.org/10.1016/j.dld.2020.02.011.

[3] Sorbye H, Welin S, Langer SW, Vestermark LW, Holt N, Osterlund P, et al. Predictive and prognostic factors for treatment and survival in 305 patients with advanced gastrointestinal neuroendocrine carcinoma (WHO G3): The NORDIC NEC study. Ann Oncol 2012. https://doi.org/10.1093/annonc/mds276.

[4] Walter T, Tougeron D, Baudin E, Le Malicot K, Lecomte T, Malka D, et al. Poorly differentiated gastro-entero-pancreatic neuroendocrine carcinomas: Are they really heterogeneous? Insights from the FFCD-GTE national cohort. Eur J Cancer 2017;79:158-65. https://doi.org/10.1016/j.ejca.2017.04.009.

[5] Frizziero M, Spada F, Lamarca A, Kordatou Z, Barriuso J, Nuttall C, et al. Carboplatin in Combination with Oral or Intravenous Etoposide for Extra-Pulmonary, Poorly-Differentiated Neuroendocrine Carcinomas.

Neuroendocrinology 2019;109:100-12. https://doi.org/10.1159/000497336.

[6] Ali AS, Grönberg M, Langer SW, Ladekarl M, Hjortland GO, Vestermark LW, et al. Intravenous versus oral etoposide: efficacy and correlation to clinical outcome in patients with high-grade metastatic gastroenteropancreatic neuroendocrine neoplasms (WHO G3). Med Oncol 2018;35:47. https://doi.org/10.1007/s12032-018-1103-x.

[7] Hentic O, Hammel P, Couvelard A, Rebours V, Zappa M, Palazzo M, et al. FOLFIRI regimen: an effective second-line chemotherapy after failure of etoposide-platinum 
combination in patients with neuroendocrine carcinomas grade 3. Endocr Relat Cancer 2012;19:751-7. https://doi.org/10.1530/ERC-12-0002.

[8] Hadoux J, Malka D, Planchard D, Scoazec JY, Caramella C, Guigay J, et al. Post-firstline FOLFOX chemotherapy for grade 3 neuroendocrine carcinoma. Endocr Relat Cancer 2015;22:289-98. https://doi.org/10.1530/ERC-15-0075.

[9] Couronne T, Girot P, Hadoux J, Lecomte T, Durand A, Fine C, et al. Post first-line dacarbazine or temozolomide in neuroendocrine carcinoma. Endocrine Connections 2020;9:498-505. https://doi.org/10.1530/EC-20-0192.

[10] Moertel CG, Kvols LK, O'Connell MJ, Rubin J. Treatment of neuroendocrine carcinomas with combined etoposide and cisplatin. Evidence of major therapeutic activity in the anaplastic variants of these neoplasms. Cancer 1991;68:227-32.

[11] Zhang P, Li J, Li J, Zhang X, Zhou J, Wang X, et al. Etoposide and cisplatin versus irinotecan and cisplatin as the first-line therapy for patients with advanced, poorly differentiated gastroenteropancreatic neuroendocrine carcinoma: A randomized phase 2 study. Cancer 2020;126 Suppl 9:2086-92. https://doi.org/10.1002/cncr.32750.

[12] Hainsworth JD, Spigel DR, Litchy S, Greco FA. Phase II trial of paclitaxel, carboplatin, and etoposide in advanced poorly differentiated neuroendocrine carcinoma: a Minnie Pearl Cancer Research Network Study. J Clin Oncol 2006;24:3548-54. https://doi.org/10.1200/JCO.2005.05.0575.

[13] Conroy $T$, Desseigne $F$, Ychou $M$, Bouché $O$, Guimbaud R, Bécouarn $Y$, et al. FOLFIRINOX versus gemcitabine for metastatic pancreatic cancer. $N$ Engl $J$ Med 2011;364:1817-25. https://doi.org/10.1056/NEJMoa1011923.

[14] Ychou M, Rivoire M, Thezenas S, Quenet F, Delpero J-R, Rebischung C, et al. A randomized phase II trial of three intensified chemotherapy regimens in first-line treatment of colorectal cancer patients with initially unresectable or not optimally resectable liver metastases. The METHEP trial. Ann Surg Oncol 2013;20:4289-97. https://doi.org/10.1245/s10434-013-3217-x. 
[15] Lambert A, Gavoille C, Conroy T. Current status on the place of FOLFIRINOX in

312

313

314

315

316

317

metastatic pancreatic cancer and future directions. Therap Adv Gastroenterol 2017;10:63145. https://doi.org/10.1177/1756283X17713879.

[16] Zhuo M, Guan Y, Yang X, Hong L, Wang Y, Li Z, et al. The Prognostic and Therapeutic Role of Genomic Subtyping by Sequencing Tumor or Cell-Free DNA in Pulmonary Large-Cell Neuroendocrine Carcinoma. Clin Cancer Res 2020;26:892-901. https://doi.org/10.1158/10780432.CCR-19-0556.

[17] Derks J, Leblay N, van Suylen RJ, Thunnissen E, den Bakker M, Groen HJM, et al. Genetic subtypes of large cell neuroendocrine carcinoma (LCNEC) to predict response to chemotherapy. JCO 2017;35:9061-9061. https://doi.org/10.1200/JCO.2017.35.15_suppl.9061.

[18] Tanaka H, Hijioka S, Hosoda W, Ueno M, Kobayashi N, Ikeda M, et al. Pancreatic neuroendocrine carcinoma G3 may be heterogeneous and could be classified into two distinct groups. Pancreatology 2020;20:1421-7. https://doi.org/10.1016/j.pan.2020.07.400.

[19] Le Treut J, Sault MC, Lena H, Souquet PJ, Vergnenegre A, Le Caer H, et al. Multicentre phase II study of cisplatin-etoposide chemotherapy for advanced large-cell neuroendocrine lung carcinoma: the GFPC 0302 study. Ann Oncol 2013;24:1548-52. https://doi.org/10.1093/annonc/mdt009.

[20] Dizdar L, Werner TA, Drusenheimer JC, Möhlendick B, Raba K, Boeck I, et al. BRAFV600E mutation: A promising target in colorectal neuroendocrine carcinoma. Int $\mathrm{J}$ Cancer 2019;144:1379-90. https://doi.org/10.1002/ijc.31828.

[21] Capdevila J, Arqués O, Hernández Mora JR, Matito J, Caratù G, Mancuso FM, et al. Epigenetic EGFR Gene Repression Confers Sensitivity to Therapeutic BRAFV600E Blockade in Colon Neuroendocrine Carcinomas. Clin Cancer Res 2020;26:902-9. https://doi.org/10.1158/1078-0432.CCR-19-1266.

[22] Klempner SJ, Gershenhorn B, Tran P, Lee TK, Erlander MG, Gowen K, et al. BRAFV600E Mutations in High-Grade Colorectal Neuroendocrine Tumors May Predict 
Responsiveness to BRAF-MEK Combination Therapy. Cancer Discov 2016;6:594-600. https://doi.org/10.1158/2159-8290.CD-15-1192.

[23] George J, Lim JS, Jang SJ, Cun Y, Ozretić L, Kong G, et al. Comprehensive genomic profiles of small cell lung cancer. Nature 2015;524:47-53. https://doi.org/10.1038/nature14664.

[24] Rekhtman N, Pietanza MC, Hellmann MD, Naidoo J, Arora A, Won H, et al. Next-

344 Generation Sequencing of Pulmonary Large Cell Neuroendocrine Carcinoma Reveals Small Cell Carcinoma-like and Non-Small Cell Carcinoma-like Subsets. Clin Cancer Res 2016;22:3618-29. https://doi.org/10.1158/1078-0432.CCR-15-2946.

[25] Sahnane N, Furlan D, Monti M, Romualdi C, Vanoli A, Vicari E, et al. Microsatellite unstable gastrointestinal neuroendocrine carcinomas: a new clinicopathologic entity. Endocr Relat Cancer 2015;22:35-45. https://doi.org/10.1530/ERC-14-0410.

[26] Kulke MH, Wu B, Ryan DP, Enzinger PC, Zhu AX, Clark JW, et al. A phase II trial of irinotecan and cisplatin in patients with metastatic neuroendocrine tumors. Dig Dis Sci 2006;51:1033-8. https://doi.org/10.1007/s10620-006-8001-3.

[27] Yamaguchi T, Machida N, Morizane C, Kasuga A, Takahashi H, Sudo K, et al. Multicenter retrospective analysis of systemic chemotherapy for advanced neuroendocrine carcinoma of the digestive system. Cancer Sci 2014;105:1176-81. https://doi.org/10.1111/cas.12473.

357 [28] Ramella Munhoz R, de Mendonça Rego JF, de Celis Ferrari AR, Ignez Braghiroli M, 358 Mendonça Bariani G, Marcelo Hoff $\mathrm{P}$, et al. Combination of irinotecan and a platinum agent for 359 poorly differentiated neuroendocrine carcinomas. Rare Tumors 2013;5:e39. 360 https://doi.org/10.4081/rt.2013.e39.

361 [29] Lokesh KN, Anand A, Lakshmaiah KC, Babu KG, Lokanatha D, Jacob LA, et al. Clinical profile and treatment outcomes of metastatic neuroendocrine carcinoma: A single institution experience. South Asian J Cancer 2018;7:207-9. https://doi.org/10.4103/sajc.sajc_176_17. 
364 [30] Yoon SE, Kim JH, Lee SJ, Lee J, Park SH, Park JO, et al. The impact of primary tumor 365 site on outcomes of treatment with etoposide and cisplatin in grade 3 gastroenteropancreatic neuroendocrine carcinoma. J Cancer 2019;10:3140-4. https://doi.org/10.7150/jca.30355.

367 [31] Bukhari MH, Coppola D, Nasir A. Clinicopathologic analysis of primary gastroenteropancreatic poorly differentiated neuroendocrine carcinoma; $A$ ten year retrospective study of 68 cases at Moffit Cancer Center. Pak J Med Sci 2020;36:265-70. https://doi.org/10.12669/pjms.36.2.1336.

371 [32] Mitry E, Baudin E, Ducreux M, Sabourin JC, Rufié P, Aparicio T, et al. Treatment of poorly differentiated neuroendocrine tumours with etoposide and cisplatin. $\mathrm{Br} \mathrm{J}$ Cancer 1999;81:1351-5. https://doi.org/10.1038/sj.bjc.6690325.

374 [33] Iwasa S, Morizane C, Okusaka T, Ueno H, Ikeda M, Kondo S, et al. Cisplatin and etoposide as first-line chemotherapy for poorly differentiated neuroendocrine carcinoma of the

376 hepatobiliary tract and pancreas. Jpn J Clin Oncol 2010;40:313-8. 377 https://doi.org/10.1093/jjco/hyp173.

378 [34] Deutschbein T, Unger N, Yuece A, Eberhardt W, Gauler T, Lahner H, et al. 379 Chemotherapy in patients with progressive, undifferentiated neuroendocrine tumors: a single380 center experience. Horm Metab Res 2011;43:838-43. https://doi.org/10.1055/s-00311284354.

[35] Patta A, Fakih M. First-line cisplatin plus etoposide in high-grade metastatic neuroendocrine tumors of colon and rectum (MCRC NET): review of 8 cases. Anticancer Res $2011 ; 31: 975-8$.

[36] Nakano K, Takahashi S, Yuasa T, Nishimura N, Mishima Y, Sakajiri S, et al. Feasibility and efficacy of combined cisplatin and irinotecan chemotherapy for poorly differentiated neuroendocrine carcinomas. Jpn J Clin Oncol 2012;42:697-703. https://doi.org/10.1093/jjco/hys085.

389 [37] Lu ZH, Li J, Lu M, Zhang XT, Li J, Zhou J, et al. Feasibility and efficacy of combined 390 cisplatin plus irinotecan chemotherapy for gastroenteropancreatic neuroendocrine 391 carcinomas. Med Oncol 2013;30:664. https://doi.org/10.1007/s12032-013-0664-y. 
392 [38] Okita NT, Kato K, Takahari D, Hirashima Y, Nakajima TE, Matsubara J, et al. 393 Neuroendocrine tumors of the stomach: chemotherapy with cisplatin plus irinotecan is effective 394 for gastric poorly-differentiated neuroendocrine carcinoma. Gastric Cancer 2011;14:161-5. 395 https://doi.org/10.1007/s10120-011-0025-5.

396 [39] Okuma HS, Iwasa S, Shoji H, Takashima A, Okita N, Honma Y, et al. Irinotecan plus 397 cisplatin in patients with extensive-disease poorly differentiated neuroendocrine carcinoma of 398 the esophagus. Anticancer Res 2014;34:5037-41. 
Table 1: First-line chemotherapy results in gastroenteropancreatic poorly differentiated neuroendocrine carcinoma

\begin{tabular}{|c|c|c|c|c|c|c|c|}
\hline Authors & $\begin{array}{l}\mathrm{n} \\
\text { patie } \\
\text { nts }\end{array}$ & Study design & Primary & $\begin{array}{l}\text { Chemotherapy } \\
\text { regimen }\end{array}$ & $\begin{array}{l}\text { response } \\
\text { rate }(\%)\end{array}$ & $\begin{array}{l}\text { median PFS } \\
\text { (months) }\end{array}$ & $\begin{array}{l}\text { median OS } \\
\text { (months) }\end{array}$ \\
\hline \multirow[t]{3}{*}{ Zhang et al [11] } & 66 & \multirow{3}{*}{$\begin{array}{l}\text { Monocentric } \\
\text { randomized phase } \\
\text { II }\end{array}$} & \multirow{3}{*}{$\operatorname{GEP}(88 \%)$, UK(12\%) } & \multirow{3}{*}{$\begin{array}{l}\text { Etoposide/cisplati } \\
\mathrm{n} \\
\text { Irinotecan/cisplatin }\end{array}$} & & & \\
\hline & 33 & & & & 44 & 6.4 & 11.3 \\
\hline & 33 & & & & 44 & 5.8 & 10.2 \\
\hline $\begin{array}{l}\text { Hainsworth et } \\
\text { al [12] }\end{array}$ & 78 & \multirow{2}{*}{$\begin{array}{l}\text { Multicentric } \\
\text { monoarm Phase II } \\
\text { Monocentric } \\
\text { phase II }\end{array}$} & \multirow{2}{*}{$\begin{array}{l}\text { UK }(62 \%), \quad \text { GEP(19\%), } \\
\text { lung }(9 \%) \\
\text { GEP }(84 \%) \text {, UK }(11 \%) \text {, lung } \\
(5 \%)\end{array}$} & $\begin{array}{l}\text { Etoposide/carbopl } \\
\text { atin/paclitaxel }\end{array}$ & 53 & 7.5 & 14.5 \\
\hline Kulke et al [26] & 4 & & & Irinotecan/cisplatin & 25 & 4.5 & 11.4 \\
\hline \multirow{3}{*}{$\begin{array}{l}\text { Sørbye et al \& } \\
\text { ali et al }[3,6]\end{array}$} & 252 & & & & & & \\
\hline & 129 & \multirow[t]{2}{*}{$\begin{array}{l}\text { Multicentric } \\
\text { retrospective }\end{array}$} & \multirow[t]{2}{*}{ GEP $(69 \%)$, UK (31\%) } & \multirow{2}{*}{$\begin{array}{l}\text { Etoposide/cisplati } \\
\mathrm{n} \\
\text { Etoposide/carbopl } \\
\text { atin }\end{array}$} & 31 & 4 & 12 \\
\hline & 67 & & & & 30 & 4 & 11 \\
\hline \multirow{3}{*}{$\begin{array}{l}\text { Yamaguchi et } \\
\text { al [27] }\end{array}$} & 258 & & & & & & \\
\hline & 160 & \multirow{2}{*}{$\begin{array}{l}\text { Multicentric } \\
\text { retrospective }\end{array}$} & \multirow[t]{2}{*}{ GEP (100\%) } & \multirow{2}{*}{$\begin{array}{l}\text { Irinotecan/cisplatin } \\
\text { Etoposide/cisplati } \\
\mathrm{n}\end{array}$} & 50 & 5.2 & 13 \\
\hline & 46 & & & & 28 & 4 & 7 \\
\hline Walter et al [4] & 253 & $\begin{array}{l}\text { Multicentric } \\
\text { retrospective }\end{array}$ & GEP (80\%) UK (20\%) & $\begin{array}{l}\text { Etoposide/platinu } \\
\mathrm{m}\end{array}$ & 50 & 6.2 & 11.6 \\
\hline \multirow{3}{*}{$\begin{array}{l}\text { Frizziero et al } \\
{[5]} \\
\text { Ramella et al } \\
{[28]} \\
\text { Lokesh et al } \\
{[29]}\end{array}$} & 98 & $\begin{array}{l}\text { Bicentric } \\
\text { retrospective }\end{array}$ & $\begin{array}{l}\text { GEP }(54 \%) \text {, UK (23\%), GU } \\
(21 \%)\end{array}$ & $\begin{array}{l}\text { Etoposide/carbopl } \\
\text { atin }\end{array}$ & 48 & 5.8 & 11.6 \\
\hline & 27 & $\begin{array}{l}\text { Bicentric } \\
\text { retrospective }\end{array}$ & GEP(64\%), UK(21\%) & Irinotecan/cisplatin & 46.4 & 3.7 & 11.7 \\
\hline & 114 & $\begin{array}{l}\text { Monocentric } \\
\text { retrospective }\end{array}$ & $\begin{array}{l}\text { GEP }(33 \%) \text {, lung(26\%), GU } \\
(15 \%), \mathrm{HN}(14 \%), \mathrm{UK}(9 \%)\end{array}$ & $\begin{array}{l}\text { Etoposide/platinu } \\
\mathrm{m}\end{array}$ & 24 & NR & 11 \\
\hline Yoon et al [30] & 64 & $\begin{array}{l}\text { Monocentric } \\
\text { retrospective }\end{array}$ & GEP $(87,5 \%)$, UK(12,5\%) & $\begin{array}{l}\text { Etoposide/cisplati } \\
\mathrm{n}\end{array}$ & 28 & 3.5 & NR \\
\hline
\end{tabular}




\begin{tabular}{|c|c|c|c|c|c|c|c|}
\hline $\begin{array}{l}\text { Bukhari et al } \\
\text { [31] }\end{array}$ & 58 & $\begin{array}{l}\text { Monocentricretros } \\
\text { pective }\end{array}$ & GEP (100\%) & $\begin{array}{l}\text { Etoposide/platinu } \\
\mathrm{m}\end{array}$ & NR & NR & $\begin{array}{l}85 \% \text { at } 1 \\
\text { year }\end{array}$ \\
\hline Mitry et al [32] & 41 & $\begin{array}{l}\text { Monocentric } \\
\text { retrospective }\end{array}$ & $\begin{array}{l}\text { GEP (20), lung (10), HN (4), } \\
\text { UK (7) }\end{array}$ & $\begin{array}{l}\text { Etoposide/cisplati } \\
\mathrm{n}\end{array}$ & 41.5 & 8.9 & 15 \\
\hline Iwasa et al [33] & 21 & $\begin{array}{l}\text { Monocentric } \\
\text { retrospective }\end{array}$ & Pancreas \& biliary (100\%) & $\begin{array}{l}\text { Etoposide/cisplati } \\
\mathrm{n}\end{array}$ & 14 & 1,8 & 5.8 \\
\hline $\begin{array}{l}\text { Moertel et al } \\
{[10]}\end{array}$ & 18 & $\begin{array}{l}\text { Monocentric } \\
\text { retrospective }\end{array}$ & GEP (14), lung (1), UK (3) & $\begin{array}{l}\text { Etoposide/cisplati } \\
\mathrm{n}\end{array}$ & 67 & 11 & 19 \\
\hline $\begin{array}{l}\text { Deutschbein et } \\
\text { al [34] }\end{array}$ & 18 & $\begin{array}{l}\text { Monocentric } \\
\text { retrospective }\end{array}$ & $\begin{array}{l}\text { GEP }(60 \%) \text {, UK }(30 \%) \text {, other } \\
(10 \%)\end{array}$ & $\begin{array}{l}\text { Etoposide/cisplati } \\
\mathrm{n} \text { or carboplatin }\end{array}$ & 17 & 6.3 & NR \\
\hline Patta et al [35] & 8 & $\begin{array}{l}\text { Monocentric } \\
\text { retrospective }\end{array}$ & Colo-rectal $(100 \%)$ & $\begin{array}{l}\text { Etoposide/cisplati } \\
\mathrm{n}\end{array}$ & 62.5 & 4.5 & 9.5 \\
\hline $\begin{array}{l}\text { Nakano et al } \\
{[36]}\end{array}$ & 30 & $\begin{array}{l}\text { Monocentric } \\
\text { retrospective }\end{array}$ & $\begin{array}{l}\text { HN (41\%), UK (28\%), GEP } \\
(20 \%), \text { GU }(9 \%)\end{array}$ & Irinotecan/cisplatin & 46 & 4.5 & 14.3 \\
\hline Lu et al [37] & 16 & $\begin{array}{l}\text { Monocentric } \\
\text { retrospective }\end{array}$ & GEP $(94 \%)$, UK (6\%) & Irinotecan/cisplatin & 57 & 5.5 & 10.6 \\
\hline Okita et al [38] & 12 & $\begin{array}{l}\text { Monocentric } \\
\text { retrospective }\end{array}$ & stomach (100\%) & Irinotecan/cisplatin & 75 & 7 & 10.4 \\
\hline $\begin{array}{l}\text { Okuma et al } \\
\text { [39] }\end{array}$ & 12 & $\begin{array}{l}\text { Monocentric } \\
\text { retrospective }\end{array}$ & oesophagus (100\%) & Irinotecan/cisplatin & 50 & 4 & 12.6 \\
\hline
\end{tabular}

Legend: GEP = gastroenteropancreatic, UK = unknown primary, $\mathrm{HN}=$ Head and neck primary, GU = Genitourinary primary, $\mathrm{PFS}=$ progressionfree survival, OS = overall survival, NR $=$ Not reported 


\section{Table 2: Main inclusion and exclusion criteria}

\section{Inclusion criteria}

- Poorly differentiated neuroendocrine carcinoma or high grade MiNEN with a NEC component $\geq 30 \%$

- Small cell or large cell or non-small cell or unknown/undetermined subtype

- gastro-entero-pancreatic or unknown origin

- Metastatic disease

- First-line treatment

- At least one measurable lesion according to RECIST 1.1 guidelines (CT-scan)

- Age $\geq 18$ years

- ECOG Performance Status $\leq 1$ (Appendix 4)

- Available tumor block

- Absolute neutrophil count $\geq 1.5 \times 10^{9} / \mathrm{l}$, platelet $\geq 100 \times 10^{9} / \mathrm{l}$ and hemoglobin $>8$ g/dl

- Total bilirubin $\leq 1.5 \mathrm{~N}, \mathrm{AST} \leq 2.5 \mathrm{~N}, \mathrm{ALT} \leq 2.5 \mathrm{~N}$ or $\mathrm{AST}$ and $\mathrm{ALT} \leq 5 \mathrm{~N}$ in case of liver metastases.

\section{Exclusion criteria}

- Grade 3 well differentiated neuroendocrine tumor according to WHO 2017 classification

- Symptomatic brain metastases*.

- Previously treated by chemotherapy or targeted therapy

- History or know hypersensitivity to any of the study chemotherapy agents, or their excipients.

- Known or historical active infection with HIV, or known active viral hepatitis

- Pre-existing permanent neuropathy ( $\mathrm{NCI}$ CTC $\vee 4.0$ grade $\geq 2$ )

- Known Gilbert's syndrome

- Pregnant women or breastfeeding mother

- History of prior malignancy, in the three years before randomization except for cured non-melanoma skin cancer and cured in situ cervical carcinoma

- Active or suspected acute or chronic uncontrolled disease that would induce excess risk associated with study participation.

- Patient under guardianship and/or deprived of his/her freedom

- Partial or complete Dihydropyrimidine Dehydrogenase deficiency (uracilemia $\geq$ $16 \mathrm{ng} / \mathrm{mL}$ )

- Severe renal impairment (creatinine clearance less than $30 \mathrm{~mL} / \mathrm{min}$, according to Cockroft and Gault Formula)

- QTc interval > $450 \mathrm{msec}$ for male and $>470 \mathrm{msec}$ for female at EKC.

- $\mathrm{K}+<$ lower limit of normal (LLN), $\mathrm{Mg}^{2}+<\mathrm{LLN}, \mathrm{Ca}^{2}+<\mathrm{LLN}$ 
${ }^{*}$ Patient with asymptomatic brain metastases or under stable corticosteroid doses for at least 2 weeks before randomization can be included.

\section{Figure 1: FOLFIRINEC study design}

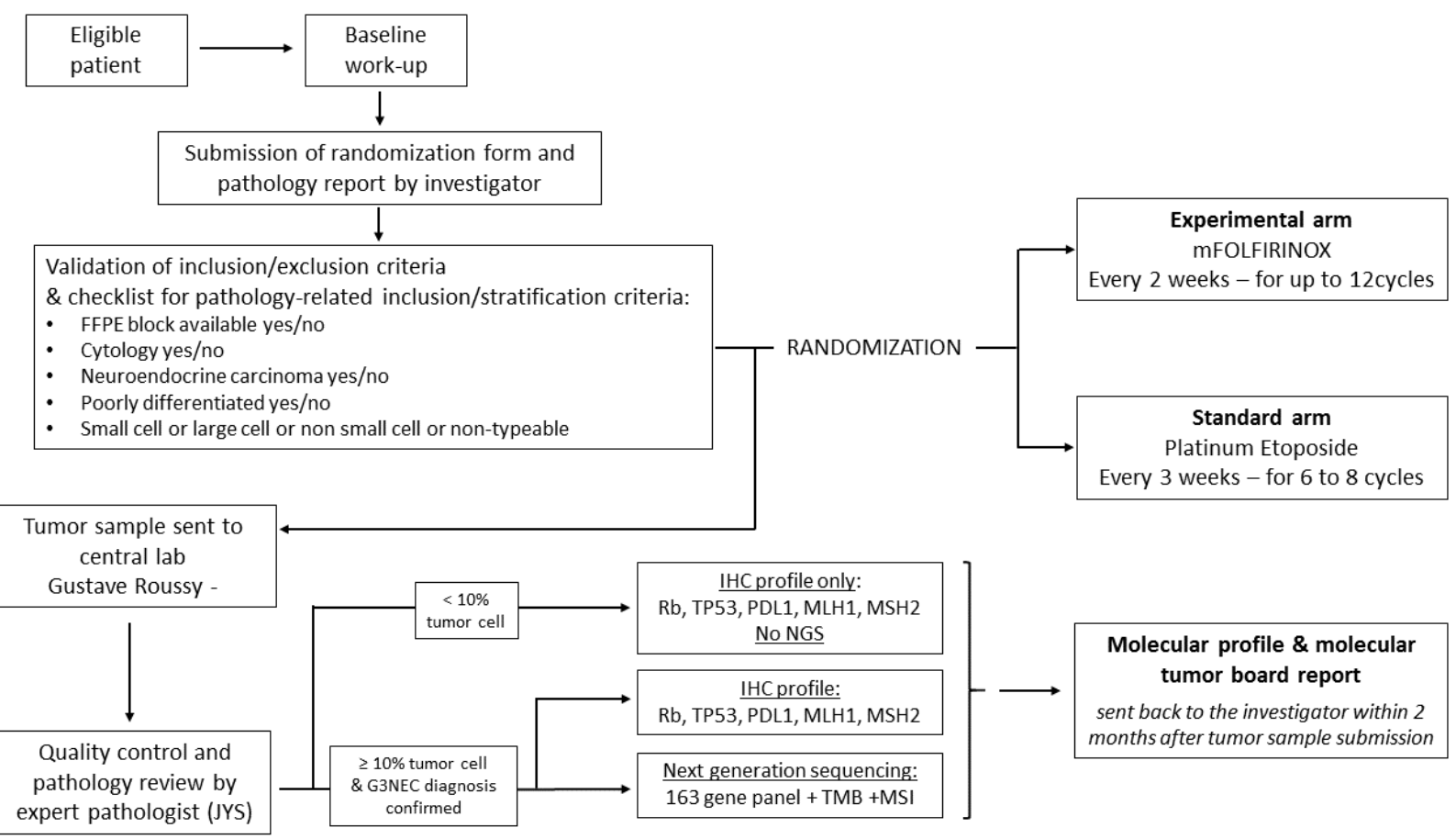

